\title{
For debates
}

\section{Thiazide-induced hyperglycaemia: a role for calcium-activated potassium channels?}

\author{
P.Pickkers $^{1}$, M.Schachter ${ }^{1}$, A.D. Hughes ${ }^{1}$, M.D. Feher ${ }^{2}$, P.S.Sever ${ }^{1}$ \\ ${ }^{1}$ Department of Clinical Pharmacology, St. Mary's Hospital Medical School, London, UK \\ ${ }^{2}$ Department of Clinical Pharmacology, Charing Cross and Westminster Hospital Medical School, London, UK
}

Thiazide diuretics have been first-line treatment for hypertension for over 30 years and their efficacy has been reinforced by recent trials, especially in elderly patients (Table 1) $[1,2]$. However, almost from the time of their introduction there has been concern about their metabolic effects, including hypokalaemia and other electrolyte disturbances. More controversially, most but not all reports indicated that the thiazides may impair glucose tolerance in non-diabetic subjects [3] and can aggravate diabetes mellitus, particularly in non-insulin-dependent (NIDDM) patients [4]. This is generally regarded as a dose-related adverse effect $[5,6]$ but there is also a temporal component which has emerged during long-term followup of thiazide-treated patients [7]. The glucose intolerance is usually reversible after discontinuation of treatment $[6,8]$, though this may take 6 months or more. It has been suggested that this 'wrong direction' side-effect of thiazides could be one of the reasons of the relatively modest - but still significant protective effect towards ischaemic heart disease [9], although there is no direct evidence for this view.

Although glucose intolerance may develop in about $3 \%$ of hypertensive patients treated with thiazide diuretics $[6,8]$ the mechanism underlying this side effect has only been sparsely studied and remains largely unknown. Several potential mechanisms have been proposed. These can be grouped under two headings:

- inhibition of insulin secretion by the beta cell, either directly or secondary to hypokalaemia $[4,10]$

Corresponding author: Dr. M. Schachter, Department of Clinical Pharmacology, St. Mary's Hospital, London W2 1NY, UK

Abbreviations: $\mathrm{K}_{\text {ATP }}$ ATP-depdent potassium channnel; NIDDM, non-insulin-dependent diabetes mellitus; $\mathrm{K}_{\mathrm{Ca}}$, calcium-activated potassium channel; $\mathrm{pH}_{\mathrm{i}}$, intracellular $\mathrm{pH}$.
- reduction in peripheral sensitivity to insulin, again either as a direct effect or as a consequence of hypokalaemia and hypomagnesaemia [11-13].

It has also been suggested that hypokalaemia is an aggravating factor rather than a primary stimulus in diuretic-associated hyperglycaemia [14].

From the literature we have noted a striking similarity of action on pancreatic beta cells and the vascular system of drugs that modulate potassium channels. On the basis of these reports and of our own experiments on the vascular effects of hydrochlorothiazide and related compounds, we propose a novel hypothesis regarding the mechanism of the diabetogenic effects of thiazides.

In the pancreas, depolarization of the plasma membrane by closure of potassium channels and opening of cation and chloride channels leads to a opening of voltage dependent calcium channels and influx of calcium [15-17]. The resultant increase of intracellular calcium is crucial to the process of insulin release. Diazoxide, a drug structurally related to the thiazides, hyperpolarizes pancreatic beta cells by opening a specific class of ATP-dependent potassium $\left(\mathrm{K}_{\mathrm{ATP}}\right)$ channels and the consequent hyperpolarization impairs

Table 1. Thiazides and thiazide-like diuretics in clinical use

Thiazides
Bendroflumethiazide (= bendrofluazide)
Chlorothiazide
Cyclopenthiazide
Hydrochlorothiazide
Hydroflumethiazide
Structurally related drugs with similar properties
Chlorthalidone
Metolazone
Xipamide

Structurally related drugs with possible differences in mechanism Cicletanine Indapamide 
insulin release [18-20]. For this reason diazoxide is used in the management of hypoglycaemia due to insulinoma. It is believed that the potassium channelopening properties of diazoxide are also responsible for its vasorelaxant activity in vitro and in vivo [21, 22]. Both pancreatic and vascular effects of diazoxide can be inhibited by sulphonylurea derivatives such as glibenclamide [19,20, 23], which are used in NIDDM $[24,25]$. Sulphonylureas close $\mathrm{K}_{\text {АTP }}$ channels resulting in depolarization of the beta-cell membrane, thereby promoting an influx of calcium via the opening of voltage-dependent calcium channels [19,20]. Other openers of the $\mathrm{K}_{\mathrm{ATP}}$ channel, such as nicorandil and pinacidil, also inhibit insulin secretion [26, 27], although at concentrations much higher than required for smooth muscle cell relaxation. In fact, during clinical use nicorandil does not significantly affect the plasma glucose level [28]. By contrast, conventional thiazides do not interact with this type of potassium channel.

\section{Calcium-activated potassium channels}

Like the $\mathrm{K}_{\mathrm{ATP}}$ channel, the large-conductance calcium-activated potassium $\left(\mathrm{K}_{\mathrm{Ca}}\right)$ channel is also expressed in both pancreatic beta cells [25] and vascular smooth muscle cells [26]. In the beta cell of the rat the $\mathrm{K}_{\mathrm{Ca}}$ channel can be blocked by quinine [25], although it must be stressed that quinine is not selective for these channels. In humans, treatment with quinine is associated with hypoglycaemia due to stimulation of insulin release [27], presumably due at least in part to inhibition of $\mathrm{K}_{\mathrm{Ca}}$ channnels. Quinine is also known to cause inner ear disturbances including tinnitus, hearing loss, and vertigo and this is thought to be due at least in part to vasoconstriction [28] and consequent ischaemia [29]. Such a hypothesis is consistent with the increasingly recognized role of $\mathrm{K}_{\mathrm{Ca}}$ channels in the regulation of vascular tone [30].

It has recently been reported that hydrochlorothiazide at low concentrations $(0.1-1.0 \mu \mathrm{mol} / \mathrm{l})$ reduces insulin release in vitro. This was associated with a fall in glucose-stimulated ${ }^{45} \mathrm{Ca}^{2+}$ uptake in beta cells [31]. As discussed above influx of calcium is one of the most distal steps in stimulus-secretion coupling in pancreatic beta cells and is crucial to insulin release [16]. As we will describe in the following section, the action of hydrochlorothiazide on calcium influx into the pancreatic beta cell shows a striking similarity with its effect on calcium entry into vascular smooth muscle cells.

\section{New experimental data}

The mechanism of the antihypertensive effect of the thiazides remains controversial. There is general agreement that there is a reduction in plasma volume during the first 1 or 2 weeks of thiazide therapy, which is usually commensurate with the fall in blood pressure. However, with continued treatment the plasma volume tends to return to normal while the blood pressure reduction is maintained, implying that peripheral resistance must be diminished. Several reports have supported this hypothesis by more direct estimation of the peripheral resistance [32]. The mechanism of the vascular effect is not understood.

Our group has been among the very few to study the acute vascular effects of the thiazides. In experiments with isolated guinea-pig arteries and vessels from human subcutaneous fat we have found that hydrochlorothiazide relaxes vascular smooth muscle cells in clinically relevant concentrations [33] through inhibition of calcium influx [34]. This effect of hydrochlorothiazide is associated with an increase in ${ }^{86} \mathrm{Rb}^{+}$ efflux, a marker of $\mathrm{K}^{+}$efflux, [35] indicating that hydrochlorothiazide increases membrane permeability to $\mathrm{K}^{+}$ions, probably by opening $\mathrm{K}^{+}$channels. The effects of hydrochlorothiazide on vascular tone, $\left[\mathrm{Ca}^{2+}\right]_{\mathrm{i}}$ and ${ }^{86} \mathrm{Rb}^{+}$efflux were inhibited by charybdotoxin and iberiotoxin, both relatively selective blockers of $\mathrm{K}_{\mathrm{Ca}}$ channels $[33,34]$. By contrast the $\mathrm{K}_{\mathrm{ATP}}$ channel blocker glibenclamide, and apamin, a blocker of small conductance $\mathrm{K}_{\mathrm{Ca}}$ channels, did not affect hydrochlorothiazide-induced vasorelaxation or ${ }^{86} \mathrm{Rb}^{+}$efflux [35]. This is consistent with a previous report showing that hydrochlorothiazide does not affect the opening of single $\mathrm{K}_{\mathrm{ATP}}$ channels in the beta-cell plasma membrane [36]. These data suggest that the opening of $\mathrm{K}_{\mathrm{Ca}}$ channels rather than $\mathrm{K}_{\mathrm{ATP}}$ channels mediates acute effects of thiazides on vascular smooth muscle cells. Interestingly electrophysiological studies have shown that cicletanine, a thiazide-like drug containing a furopyridine group, causes membrane hyperpolarisation in isolated canine femoral arteries [37] probably by an action on $\mathrm{K}_{\mathrm{Ca}}$ channels. Since these channels are present in pancreatic beta cells [25] and by analogy with the potassium channel opening properties of diazoxide it is very likely that the effect of hydrochlorothiazide on $\mathrm{K}_{\mathrm{Ca}}$ channels would be to hyperpolarise the beta-cell membrane, leading to reduced insulin release. This effect could explain the inhibitory action of hydrochlorothiazide on insulin secretion.

At present it is unclear how thiazides act on $\mathrm{K}_{\mathrm{Ca}}$ channels. It is possible that they interact directly with the $\mathrm{K}_{\mathrm{Ca}}$ channel, but an indirect effect on the channel via an intracellular signalling mechanism is also possible. Ongoing studies in our department suggest that the $\mathrm{K}^{+}$channel opening properties of hydrochlorothiazide may depend on changes in intracellular $\mathrm{pH}\left(\mathrm{pH}_{\mathrm{i}}\right)$. Effects of hydrochlorothiazide on $\mathrm{pH}_{\mathrm{i}}$ appear, in turn, to be associated with the ability of the drug to inhibit carbonic anhydrase activity [38]. Others have shown that pre-treatment with acetazolamide, an inhibitor of carbonic anhydrase, caused glucose intolerance in mice and reduced secretion of insulin in isolated pancreatic islets [39], 


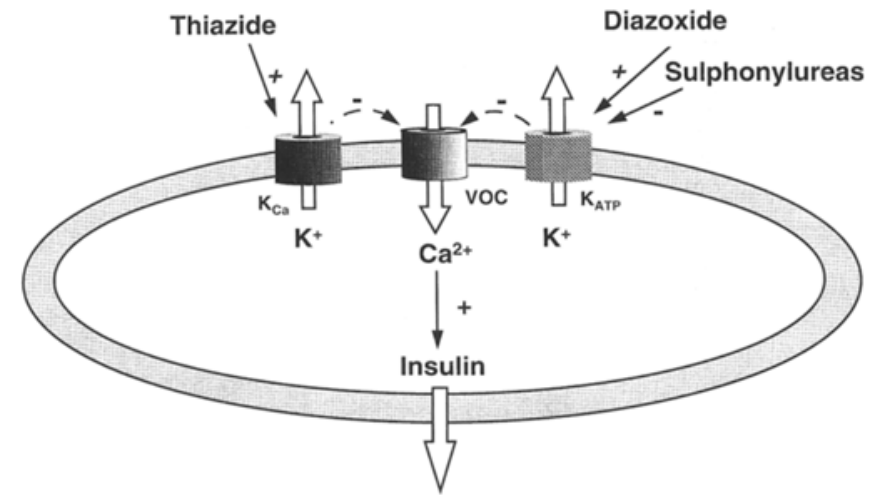

Fig. 1. Representation of hypothesis. Activation of ATP-sensitive potassium channels $\left(K_{\mathrm{ATP}}\right)$ or of large-amplitude calciumactivated potassium channels $\left(\mathrm{K}_{\mathrm{Ca}}\right)$ increase potassium conductance and hyperpolarise the cell membrane in the pancreatic beta cells, thereby reducing calcium entry through voltage-operated calcium channels (VOC) and so inhibiting insulin secretion

although no human data is available for this drug. However, it should be emphasised that direct evidence concerning the role of carbonic anhydrase inhibiting activity is lacking, though we have found the vasorelaxant action of bendroflumethiazide, a very weak inhibitor of carbonic anhydrase [38], to be much smaller than that of acetazolamide and hydrochlorothiazide and this action was not inhibited by charybdotoxin. This suggests that bendroflumethiazide does not act on $\mathrm{K}_{\mathrm{Ca}}$ channels.

\section{Summary and hypothesis}

We can therefore summarise the following experimental findings, partly from our own studies and partly from the work of other groups:

- calcium influx is an essential component in stimulus-secretion coupling in pancreatic beta-cells and excitation-contraction coupling in vascular smooth muscle cells

- thiazides inhibit calcium influx in these cells

- thiazides (e.g. $10 \mu \mathrm{mol} / 1$ hydrochlorothiazide) also inhibit calcium entry in small mesenteric arteries

- in vascular smooth muscle thiazides increase potassium permeability probably via large conductance $\mathrm{K}_{\mathrm{Ca}}$ channels, resulting in membrane hyperpolarisation and the closure of voltage-operated calcium channels.

We therefore propose the hypothesis illustrated in Figure 1 as an explanation for at least part of the adverse effect of thiazides on glucose homeostasis: in the absence of direct experimental evidence it omits mention of the possible role of carbonic anhydrase inhibition. In summary:

1. Thiazide diuretics directly or indirectly open the large-conductance $\mathrm{K}_{\mathrm{Ca}}$ channel in the plasma membrane of the pancreatic beta cell.
2. This increases potassium permeability and causes hyperpolarisation of the membrane, inhibiting calcium influx through voltage-operated calcium channels. 3 . The reduction in intracellular calcium attenuates insulin release by the beta cell.

We do not know if the interaction with this class of ion channels is a significant mechanism for the chronic antihypertensive effects of the thiazides and we are not making any such proposal in our hypothesis. Our in vitro studies relate to acute responses to relatively high drug concentrations and may be of limited relevance for drugs which take weeks to achieve their maximal blood pressure-lowering effects. On the other hand it is known for the thiazide-like drug indapamide that during chronic treatment accumulation of the drug in the vascular smooth muscle cell takes place to levels 9 times greater than the plasma concentration [40].

It is entirely possible that other, peripheral, diabetogenic actions of thiazides may be important. However, we believe that ours is a plausible hypothesis. It raises the possibility that thiazides or thiazide-like drugs can be developed with few if any metabolic side-effects. Indapamide is structurally related to the thiazides but does not interact with $\mathrm{K}_{\mathrm{Ca}}$ and $\mathrm{K}_{\mathrm{ATP}}$ channels [33] and has less effect on glucose, lipid and uric acid homeostasis [41]. Its exact mode of action remains uncertain, though it may act partly through blockade of voltage-operated calcium channels [33, 42].

It should be noted that attempts have been made to synthesise compounds specificially intended to interact with $\mathrm{K}_{\mathrm{Ca}}$ channels, but to date these are neither potent nor selective [43].

Acknowledgements. Supported by the British Heart Foundation and the Dutch Heart Foundation.

\section{References}

1. Ekbom T, Dahlöf B, Hansson L, Lindholm LH, Scherstén B, Wester PO (1992) Antihypertensive efficacy and side effects of three beta blockers and a diuretic in elderly hypertensives: a report from the STOP-hypertension study. J Hypertens 10: 1525-1530

2. Moye LA, Davis BR, Hawkins CM, Probstfield JL (1993) Conclusions and implications of the Systolic Hypertension in the Elderly Program. Clin Exp Hypertens 15: 911-924

3. Wilkins RW (1959) New drugs for the treatment of hypertension. Ann Int Med 50: 1-10

4. Weinberger MH (1992) Mechanisms of diuretic effects on carbohydrate tolerance, insulin sensitivity and lipid levels. Eur Heart J 13[Suppl G]:5-9

5. McVeigh GH, Dulie EB, Ravenscroft A, Galloway DB, Johnston GD (1989) Low and conventional dose cyclopenthiazide on glucose and lipid metabolism in mild hypertension. Br J Clin Pharmac. 27: 523-526

6. Carlsen RH, Kober L, Torp-Petersen C, Johansen P (1990) Relation between dose of bendrofluazide, antihypertensive effect and adverse biochemical effects. BMJ 300: 975-978

7. Murphy MB, Lewis RJ, Kohner E, Schiemer B, Dollery CT (1982) Glucose tolerance in hypertensive patients treated 
with diuretics: a fourteen-year follow-up. Lancet 2: 12931295

8. Knauf H (1993) The role of low-dose diuretics in essential hypertension. J Cardiovasc Pharmacol 22[Suppl 6]:S1-S7

9. Black HR (1990) The coronary artery disease paradox: the role of hyperinsulinemia and insulin resistance and implications for therapy. J Cardiovasc Pharmacol 15[Suppl 5]: S26-S38

10. Fajans SS, Floyd JC, Knopf RF, Bull J, Guntsche EM, Conn JW (1966) Benzothiadiazide suppression of insulin release from normal and abnormal islet cell tissue in man. $\mathrm{J}$ Clin Invest 45: 481-493

11. Pollare T, Lithell H, Berne C (1989) A comparison of the effects of hydrochlorothiazide and captopril on glucose and lipid metabolism in patients with hypertension. $\mathrm{N}$ Engl J Med 321: 868-873

12. Andersson OK, Gudbrandsson T, Jamerson K (1991) Metabolic adverse effects of thiazide diuretics: the importance of normokalaemia. J Int Med 229[Suppl 2]: 89-96

13. Yajnik CS, Smith RF, Hockaday TD, Ward NI (1984) Fasting magnesium concentrations and glucose disposal in diabetes. BMJ Clin Res 288: 1032-1034

14. Furman BL (1981) Impairment of glucose tolerance by diuretics and other drugs. Pharmacol Ther 12: 613-649

15. Sehlin J (1978) Interrelationship between chloride fluxes in pancreatic islets and insulin release. Am J Physiol 235: 501508

16. Wollheim C, Sharp GWG (1981) Regulation of insulin release by calcium. Physiol Rev 61: 914-973

17. Pedersen OH, Findlay I (1987) Electrophysiology of the pancreas. Physiol Rev 67: 1054-1116

18. Malaisse WJ, Malaisse-Lagae F (1968) Effect of thiazides upon insulin secretion in vitro. Arch Int Pharmacodynam 171: 235-239

19. Henquin JC, Meissner HP (1982) Opposite effects of tolbutamide and diazoxide on ${ }^{86} \mathrm{Rb}^{+}$fluxes and membrane potential in pancreatic beta-cells. Biochem Pharmacol 31: $1407-1415$

20. Trube G, Roosman P, Ohno-Shusaku T (1986) Opposite effects of tolbutamide and diazoxide on the ATP dependent $\mathrm{K}^{+}$channel in mouse pancreatic beta-cells. Pflüger's Arch 407: 493-499

21. Edwards G, Weston AH (1990) Potassium channel openers and vascular smooth muscle relaxation. Pharmac Ther 48: 237-258

22. Edwards G, Weston AH (1993) The pharmacology of ATPsensitive potassium channels. Annu Rev Pharmacol Toxicol 33: 597-637

23. Bijlstra PJ, Smits P, Lutterman JA, Thien T (1994) Glibenclamide inhibits the vasodilator effect of diazoxide in man. J Hypertens 12: 5104

24. Groop LC (1992) Sulfonylureas in NIDDM. Diabetes Care 15: $737-754$

25. Gerich JE (1989) Oral hypoglycemic agents. N Engl J Med 321: 1231-1245

26. Pratz J, Mondot S, Montier F, Cavero I (1991) Effects of the $\mathrm{K}^{+}$channel activators, RP 52891, cromakalim and diazoxide, on the plasma insulin level, plasma renin activity and blood pressure in rats. J Pharmacol Exp Ther 258: 216-222

27. Dunne MJ (1990) Effects of pinacidil, RP 49356 and nicorandil on ATP-sensitive potassium channels in insulin-secreting cells. Br J Pharmacol 99: 487-492

28. Krumenacker M, Roland E (1992) Clinical profile of nicorandil: an overview of its hemodynamic properties and therapeutic efficacy. J Cardiovasc Pharmacol 20 (Suppl 3): S93-S102
25. Mancilla E, Rojas E (1990) Quinine blocks the high conductance, calcium-activated potassium channel in rat pancreatic beta-cells. FEBS Letts 260: 105-108

26. Vazquez J, Feigenbaum P, Katz G et al. (1989) Characterization of high affinity binding sites for charybdotoxin in sarcolemmal membranes from bovine aortic smooth muscle. Evidence for a direct association with the high conductance calcium-activated potassium channel. J Biol Chem 264: 20902-20909

27. Davis TME, Karbwang J, Looareesuwan S, Turner RC, White NJ (1990) Comparative effects of quinine and quinidine on glucose metabolism in healthy volunteers. Br J Clin Pharmacol 30: 397-403

28. Smith DI, Lawrence M, Hawkins JE (1985) Effects of noise and quinine on the vessels of the stria vascularis: an image analysis study. Am J Otolaryngol 6: 280-289

29. Lee CS, Heinrich J, Jung TTK (1992) Quinine-induced ototoxicity: alterations in cochlear blood flow. Otolaryngol Head Neck Surg 107: 233

30. Nelson MT, Quayle JM (1995) Physiological roles and properties of potassium channels in arterial smooth muscle. Am J Physiol 268: C799-C822

31. Sandström PE (1993) Inhibition by hydrochlorothiazide of insulin release and calcium influx in mouse pancreatic beta-cells. Br J Pharmacol 110: 1359-1362

32. Van Brummelen P, Man in 't Veld AJ, Schalekamp MA (1980) Hemodynamic changes during long-term thiazide treatment of essential hypertension in responders and nonresponders. Clin Pharmacol Ther 27: 328-336

33. Calder JA, Schachter M, Sever PS (1992) Direct vascular actions of hydrochlorothiazide and indapamide in isolated small vessels. Eur J Pharmacol 220: 19-26

34. Pickkers P, Hughes AD (1995) Relaxation and decrease in $\left[\mathrm{Ca}^{2+}\right]_{\mathrm{i}}$ by hydrochlorothiazide in guinea-pig isolated mesenteric arteries. Br J Pharmacol 114: 703-707

35. Calder JA, Schachter M, Sever PS (1994) Potassium channel opening properties of thiazide diuretics in isolated guinea-pig resistance arteries. J Cardiovasc Pharmacol 24: $158-164$

36. Gilles KD, Gee WM, Hammond A, McDaniel ML, Falker LC, Misler S (1989) Effect of sulfonamides on metaboliteregulated $\mathrm{ATP}_{\mathrm{i}}$-sensitive $\mathrm{K}^{+}$channel in rat pancreatic beta-cells. Am J Physiol 257: 1119-1127

37. Siegel G, Schnalke F, Schultz G, Stock G (1991) K ${ }^{+}$channel opening and vascular tone. In: Mulvany MJ, Aalkjaer C, Heagerty AM, Nyborg NCB, Standgaard S (eds) Resistance arteries, structure and function. Elsevier, Amsterdam, pp 130-139

38. Beyer KH, Baer JE (1961) Physiological basis for the action of newer diuretic agents. Pharmacol Rev 13: 517-562

39. Bofquist L, Backman AM, Stromberg C (1980) Effects of acetazolamide on insulin release, serum glucose and insulin, glucose tolerance and alloxan sensitivity of mice. Med Biol 58(3): 169-173

40. Campbell DB, Taylor AR, Hopkins YW, Williams JRB (1977) Pharmacokinetics and metabolism of indapamide: a review. Curr Med Res Opin 5 [Suppl 1]: 13-24

41. Thomas JR (1985) A review of 10 years of experience with indapamide as an antihypertensive agent. Hypertension 7[Suppl II]: II-152-II-156

42. Mirroneau J (1988) Indapamide-induced inhibition of $\mathrm{Ca}^{2+}$ movement in smooth muscles. Am J Med 84: 10-14

43. Sargent CA, Grover GJ, Antonaccio MJ, McCullough JR (1993) The cardioprotective, vasorelaxant and electrophysiological profile of the large conductance calcium-activated potassium channel opener NS-004. J Pharmacol Exp Ther 266: $1422-1429$ 